\title{
Democratic Constitutionalism and Cultural Heterogeneity
}

ROBERT C POST*

The enterprise of democratic constitutionalism rests upon the premise of collective agency. If we ask who makes a democratic constitution, the answer must be given in the first person plural. In the United States, for example, our Constitution fittingly begins, 'We the People...do ordain and establish this Constitution...' The collective agency of the people constitutes a 'demos' capable of "bestowing...democratic authority on a polity."

Of course the appearance of a first person plural is a political construction; it does not correspond to any existing entity that needs merely to clear its throat in order to speak. Who 'we the people' are, and what exactly they are saying, is endlessly debatable. But those who would engage in the enterprise of democratic constitutionalism must nevertheless presuppose such a shared voice, which typically speaks in order to exercise the power of collective agency to establish the ongoing structure of a democratic state. ${ }^{2}$

All states are in some sense collective agents. States act; they make decisions, form and pursue policies, enter into treaties and contracts, enact legislation, and so forth. From the perspective of practical reason, which is to say from the perspective of entities that deliberate and decide, states, no less than persons, must possess a 'unity of agency."3

* Professor of Law, University of California at Berkeley.

1 JHH Weiler, 'Does Europe Need a Constitution? Demos, Telos and the German Maastricht Decision', (1995) 1 European Law Journal 219, 238.

2 Recent developments in the European Community represent a fascinating challenge to the proposition in text. See, eg Neil Walker, 'European Constitutionalism and European Integration', (1996) Public Law 266. But those who would argue that the Community reflects a form of constitutionalism must face the well-known problem of 'democratic deficit,' which at root relies on the fact that the 'Community draws its authority not from a constitutional enactment of some definable European 'demos' or people-the prerequisite of democratic legitimacy - but generally from lawful transfers of normative power from national parliaments as representatives of their respective national communities.' Peter L Lindseth, 'Democratic Legitimacy and the Administrative Character of Supranationalism: The Example of the European Community', (1999) 99 Columbia Law Review 628, 636-37. In Europe we may be witnessing the ongoing dynamic construction of a democratic demos.

3 Christine M Korsgaard, 'Personal Identity and the Unity of Agency: A Kantian Response to Parfit', (1989) 18 Philosophy and Public Affairs 101, 119. Korsgaard writes that a state, which is 'defined by its constitution and deliberative procedures,' 'is not merely a group of citizens living on a shared territory. We have a state only 
Democratic states must possess not only this practical unity of agency, but also the kind of normative unity that Christine Korsgaard has attributed to individual persons, a unity that is 'essentially authorial' and that depends upon regarding "our actions and choices....as our own." Democratic states embody the value of collective self-governance, which requires that citizens come to accept their own 'authorship' of state actions and choices, or at least of the deliberative procedures through which the state reaches its decisions. ${ }^{5}$ The very identity of the state as democratic depends upon this 'unifying principle" ${ }^{\prime 6}$ of identification. Although the content of the principle is ceaselessly contestable, the principle is nevertheless the premise of democratic legitimacy.

The challenge of democratic constitutionalism is to establish a governmental structure that will provide a stable institutional form for this premise. In her brief but trenchant exploration of 'The Idea of a Constitution,' Hanna Pitkin notes that there are always (at least) two aspects to a constitution. The first refers to 'something we are,' to a 'distinctive shared way of life of a polis, its mode of social and political articulation as a community. ${ }^{7}$ The second refers to something we $d o$,' to the 'capacity for human self-constituting' exercised most 'consciously and deliberately,' which is to say 'collectively. ${ }^{18}$ The two aspects of constitutionalism are related because 'how we are able to constitute ourselves is profoundly tied to how we are already constituted by our distinctive history,' by our 'fundamental ethos or temperament. 9

Pitkin's point is that a constitution can succeed in establishing durable and stable structures of democratic legitimacy only if it draws upon the foundation of a 'fundamental ethos' that reflects 'the national character of a people. ${ }^{10}$ Democratic statehood requires common commitments and identifications, which is why the mere mechanical holding of elections cannot by itself ever create a successful democratic state. These commitments and identifications must be sufficiently entrenched to survive the normal stresses and exigencies of economic and political life.

Commitments and identifications of this kind are facilitated when the

where these citizens have constituted themselves into a single agent. They have, that is, adopted a way of resolving conflicts, making decisions, interacting with other states, and planning together for an ongoing future.' Ibid 114.

Ibid 121.

Robert Post, 'Equality and Autonomy in First Amendment Jurisprudence', 95 Michigan Law Review (1997) 1517, 1523-25. Of course democratic states do not require that each individual citizen agree with every state action; that would be entirely unrealistic. Rather, democratic states remain democratic in part because each individual citizen is offered the opportunity to persuade others to alter those decisions that she may find objectionable, and because this opportunity suffices in actual operation to sustain the form of identification described in the text.

$6 \quad$ Korsgaard, above n 3, 112.

7 Hanna Fenichel Pitkin, 'The Idea of a Constitution', (1987) 37 Journal of Legal Education 167, 167-68.

$8 \quad$ Ibid 168

$9 \quad$ Ibid 169.

$10 \quad$ Ibid 167 
constitution of a state reflects the fundamental ethos of its people. It is important to be clear, however, that this ethos need not lie in the dimension of ethnicity, although contemporary discussions of 'nationality' frequently stress this characteristic. "The example of the United States demonstrates that the relevant ethos may lie instead in the dimensions of ideology or "shared values." 12

The conclusion that democratic constitutionalism must ultimately be rooted in shared cultural commitments raises the central tension that I shall address in this paper. Cultural heterogeneity has become an increasingly significant marker of postcolonial politics, and yet such heterogeneity celebrates precisely the plural values that would seem to contradict the unity required for successful democratic constitutionalism. It is necessary to explore, therefore, the ways in which cultural diversity, which powerfully tears at what Homi Bhabha has called 'the impossible unity of the nation, ${ }^{, 13}$ can be reconciled to the enterprise of democratic constitutionalism.

A democratic state can, of course, adopt many different stances toward the value of cultural heterogeneity. These range from suppressing diversity in order to establish the uniform culture believed to offer maximum support for democratic legitimacy, to tolerating cultural diversity, to actively promoting cultural heterogeneity. Much ink has been spilled over the question of which stance is most desirable. No doubt the power of claims for cultural heterogeneity will depend upon particular circumstances. Claims will have different force if evoked to eliminate the present effects of past discrimination, than if evoked to support an abstract commitment to multicultural diversity. Claims will have different force if adduced to protect the threatened culture of a conquered people with a shared language and territory, than if adduced to safeguard the continuity of a recent immigrant culture.

In these brief remarks, however, I shall not explore the varying contexts in which claims of cultural heterogeneity are brought forward. I shall instead assume that such claims are powerful and convincing, and that a state wishes to fulfil them to the full extent of its power. The question I shall discuss is whether a foundational commitment to democratic constitutionalism, of its own force, effectively limits the extent to which a state can recognise and protect cultural diversity. My aim is to explore the tension between democratic constitutionalism and cultural heterogeneity, and in particular the implications of this tension for typical legal mechanisms for promoting cultural diversity.

I.

It turns out that it is not easy directly to address this tension. One might, for

11 For a good discussion, see David Miller, On Nationality (Oxford: Clarendon Press 1995) 19-21.

12 Weiler, above $\mathrm{n} 1,243$.

13 Homi K Bhabha, 'Introduction: Narrating the Nation', in Homi K Bhabha (ed), Nation and Narration (London: Routledge Press 1990) 1. 
example, seek to determine which substantive cultural values are necessary for the social cohesion required by democratic constitutionalism. The argument might take the following form:

Value ' $z$ ' is necessary for the social cohesion required by democratic constitutionalism.

Promoting culture ' $y$,' which opposes ' $z$,' would pose a serious risk to the maintenance of ' $z$.'

Therefore culture ' $y$ ' need not be promoted.

It is very difficult to say anything general or theoretical about arguments of this kind. It is true that democratic constitutionalism requires a durable and "common commitment to the flourishing of the mutual enterprise of nationhood,"14 but the substance of this commitment can be quite various. If we think of a nation, in Renan's famous phrase, as a 'grand solidarity, ${ }^{15}$ the content of this solidarity is historically contingent. About all we can say in the abstract is the unhelpful proposition that a democratic constitution must reflect, establish and reinforce cultural uniformity with respect to those values necessary to underwrite the identifications and commitments required for the stable maintenance of a democratic state. Although 'a common past ${ }^{16}$ is often said to be prerequisite, the salient aspects of this past, the dimensions that actually sustain 'a present will to live together, ${ }^{17}$ are widely divergent and depend largely upon the particularities of historical circumstance and political judgment.

In some situations, for example, linguistic or religious diversity may constitute insuperable obstacles to the solidarity necessary to sustain democratic constitutionalism; in other circumstances, these same differences may have no great functional significance. It all depends upon how the 'distinctive shared way of life of a polis, its mode of social and political articulation as a community' has historically developed. In Canada, linguistic differentiation threatens to undermine the common commitments prerequisite for the Canadian state, whereas in Switzerland linguistic differentiation seems to have no such consequences. In Northern Ireland religious diversity renders the creation of a democratic constitutional state problematic, but in the United States religious diversity poses no such challenge.

We might perhaps get better theoretical purchase on this line of reasoning if we focus on the preconditions for democracy, instead of seeking to articulate the substantive values prerequisite for social cohesion. We thus might imagine arguments of the form:

Robert Post, Constitutional Domains (Cambridge: Harvard University Press 1995) 36.

Ernest Renan, 'Qu'est-ce qu'une nation?' in John Hutchinson \& Anthony D Smith (eds), Nationalism (Oxford: Oxford University Press 1994) 17.

Neil McCormick, 'Nation and Nationalism', in Legal Right and Social Democracy: Essays in Legal and Social Philosophy (Oxford: Oxford University Press 1982) 249. Ibid. 
A democratic state entails value ' $x$.'

Promoting culture ' $y$,' which opposes ' $x$,' would pose a serious risk to the maintenance of ' $x$.'

Therefore culture ' $y$ ' need not be promoted. 18

Arguments of this kind achieve their theoretical bite by seeking to define the nature of democracy. If democracy entails value ' $x$,' we can defend the principle that we ought not to promote a cultural diversity that is inconsistent with the maintenance of ' $x$.' Theoretical discussion can then proceed on the question of whether democracy does or does not entail value ' $x$ '; we can debate whether democracies require respect for the rule of law, or tolerance, or equal respect for persons, or critical reason. ${ }^{19}$ The upshot is that what begins as an examination of the relationship of democratic constitutionalism to cultural heterogeneity, tends to conclude as a discussion about the nature of democracy.

Of course it is important and necessary to ascertain the nature of democracy. But that is not my purpose in these brief remarks. Instead I shall try to maintain a focus on the theoretical tension between cultural heterogeneity and democratic constitutionalism by shifting the inquiry to the question of how a democratic state might promote cultural diversity. If we assume that there are in fact dimensions of cultural diversity that are compatible with democratic constitutionalism and that we therefore wish to preserve, we may inquire whether there are any theoretical insights to be gleaned about the legal mechanisms by which this may be accomplished.

There is certainly no dearth of such mechanisms. Structures of voting and representation, for example, might be constitutionally designed so as to maximise the presence of relevantly diverse legislators. ${ }^{20}$ Or a constitution could guarantee subsidies or other forms of support for culturally diverse groups. ${ }^{21}$ Or a constitution could circumscribe state power so that a state would lack the legal competence to legislate in areas deemed necessary to preserve cultural heterogeneity. The possibilities are so numerous that it seems presumptuous even to begin to list them.

I shall therefore confine my discussion to three common structural mechanisms for protecting cultural heterogeneity: individual rights, group rights, and the devolution of sovereignty. It turns out that each of these mechanisms has distinct theoretical and practical implications that shape the nature of the cultural

Notice that the argument does not reach the case of small and isolated cultures which may oppose ' $x$,' but whose opposition does not pose any realistic threat to the general social maintenance of ' $x$.' Notice also that the argument does not reach the question of whether the state is entitled to suppress culture ' $y$.' See, eg Meira Levinson, 'Liberalism, Pluralism, and Political Education: Paradox or Paradigm?', (1999) 25 Oxford Review of Education 39. See, eg Will Kymlicka, 'Group Representation in Canadian Politics', in F Leslie Seidle (ed), Equity and Community: The Charter, Interest Advocacy, and Representation (Institute for Research and Public Policy 1993). 
heterogeneity it can recognise and sustain.

II.

Individual rights function in at least two kinds of ways. Some individual rights directly align individual behaviour with cultural norms. The right to sue for defamation or invasion of privacy, for example, ensures that the law will enforce cultural standards of civility and decency. ${ }^{22}$ The 'right' penalises those who deviate from these standards. Individual rights that function in this way promote cultural uniformity, because they bring the force of the state directly to bear on conduct so as to enforce the norms of a particular, and presumably dominant, culture. ${ }^{23}$

Other kinds of individual rights, however, function in a different way. They endow individuals with decision-making power, and they immunise these decisions from state interference, even from state efforts to enforce dominant cultural norms. A classic example of this kind of right is that of freedom of speech, which safeguards the power of persons to speak, especially in ways that violate cultural norms otherwise enforced by the law of libel or privacy. By resisting legal enforcement of dominant cultural norms, such individual rights facilitate cultural heterogeneity.

Another example of such an individual right is the right to the 'free exercise' of religion. This right prevents the state from compelling religious uniformity. It endows persons with the competence to select and pursue their preferred forms of religious observance, thereby facilitating the religious diversity that flows from individual choices. Similarly, the right to linguistic freedom ${ }^{24}$ guarantees persons the power to speak and write in whatever language they decide, and it thereby also protects the linguistic heterogeneity that results from such decisions.

We may observe at least three distinct kinds of theoretical limits to the cultural heterogeneity that can be safeguarded by the mechanism of individual rights. First, individual rights that seek to create spheres of personal autonomy do so in order to advance whatever social values have been embraced by the institution of the law. Endowing persons with freedom of speech, for example, is a way of creating the social good of democratic legitimacy. ${ }^{25}$ Linguistic and religious freedoms foster the social good of a liberal and tolerant culture. ${ }^{26}$ This implies that

22 For a discussion, see Robert Post, 'The Social Foundations of Privacy: Community and Self in the Common Law Tort', (1989) 77 California Law Review 957 (hereinafter 'Social Foundations'); Robert Post, 'The Constitutional Concept of Public Discourse: Outrageous Opinion, Democratic Deliberation, and Hustler Magazine v Falwell', (1990) 103 Harvard Law Review 601.

23 Of course the norms of the dominant culture may entail a certain measure of respect for the subsidiary norms of subordinate cultures, so that the norms of the dominant culture can take on a pluralist cast. For a discussion, see Robert Post, 'Cultural Heterogeneity and Law: Pornography, Blasphemy, and the First Amendment', (1988) 76 California Law Review 297.

24 See, eg Yu Cong Eng v Trinidad, 271 U.S. 500 (1926).

25 See Post, above n 14, 6-18.

26 Post, above n 23, 321-22. 
individual rights will not protect individual autonomy when such protection is inconsistent with the social values that the law recognises as justifying enforcement of the rights. ${ }^{27}$ These social values, of course, will reflect the norms of the dominant culture. It would seem to follow that minority cultures that promote behaviour that is incompatible with these norms will be unlikely to be protected by individual rights.

Second, many norms of many cultures are anti-individualist, and these norms not only will fail to be protected by a strategy of individual rights, they may be affirmatively undermined. So, for example, the norms of a culture that believes that wives ought to be required to obey their husbands will be undercut by a legal system that endows wives with the power to act as equal partners within a marriage. Or the norms of a culture that believes in the communal ownership of land may well be savaged by individual property rights. Only the diversity of certain kinds of cultural norms, therefore, can be protected through the mechanism of individual rights.

Third, individual rights protect only that diversity capable of surviving in a market fuelled by individual choices. Individual rights do not guarantee that cultural diversity will flourish; instead they merely protect the diversity which persons choose to enjoy. Individual rights are thus not very effective guarantors of cultural heterogeneity if a dominant culture exerts a strong hegemonic influence. ${ }^{28}$ For example, if there are robust pressures to learn and converse in a dominant language, and if as a consequence persons progressively abandon the use of subsidiary languages, merely endowing individuals with the right to use such subsidiary languages will do little to preserve cultural heterogeneity. In such circumstances, alternative mechanisms, like affirmative state subsidies and support, may also be necessary.

III.

These inherent characteristics of individual rights have prompted calls for an alternative (or perhaps supplementary) mechanism to protect cultural heterogeneity. This is the mechanism of group rights. There is a large philosophical literature addressing the question of whether group rights are possible or desirable. ${ }^{29}$ In these remarks I shall not engage that literature, but instead view group rights from the practical perspective of a functioning legal system, where such rights are in fact

27 That is perhaps why fighting words are unprotected by the First Amendment to the United States Constitution. Ibid 322-24; Post, above n 14, 175-76.

28 Some commentators do not regard this is a bad thing, because if a culture withers for lack of adherents, "it is like the death of a fashion or a hobby, not the demise of anything that people rally need.' Jeremy Waldron, 'Minority Cultures and the Cosmopolitan Alternative', in Will Kymlicka (ed), The Rights of Minority Cultures (Oxford: Oxford University Press 1997) 100.

29 See, eg Christopher Heath Wellman, 'Liberalism, Communitarianism, and Group Rights', (1999) 18 Law and Philosophy 13. 
quite commonplace. $^{30}$

We should note at the outset that the concept of group rights bears no necessary relationship to cultural heterogeneity. Group rights may or may not protect cultural diversity, depending upon the extent to which distinct groups reflect distinct cultures. Some corporations are groups, these corporations hold rights, but these rights do not protect cultural diversity. Rights given to the group 'women' or to a particular racial group, may or may not protect cultural diversity, depending upon one's account of the nature of culture and of how culture is (or is not) connected to biology or to race.

If we focus our attention only on those group rights relevant to the question of cultural heterogeneity, we find that the concept of group rights is subject to further ambiguity. Rights can be viewed as group rights because groups, as distinct from individuals, are the rights-holders. We can in this way distinguish rights held by churches, corporations, or tribes, from rights held by individual persons.

But rights may also be considered group rights if they are designed to protect group interests, as distinct from individual interests. It is sometimes said that rights that serve social interests are group rights. ${ }^{31}$ But if, as I have argued, all rights serve social interests, this way of framing the question is not helpful. We must instead distinguish those interests that are understood to be shared, or potentially shared, by all persons within a political community, which I shall call 'individual interests,' from those interests that arise from membership in a group, which by definition is less than the whole community.

The right to be free from invasions of privacy, for example, protects interests that are attributed to all members of the community. This is because the right serves values important to the identity and commitments of the entire community, and hence which are conceptualised as arising from membership in the community. ${ }^{32}$ I would thus classify the right as protecting individual interests, even though it safeguards community values. Group interests, by contrast, are partial; they are not universally shared within the community. That is why Will Kymlicka accurately calls rights protecting group interests 'special rights, ${ }^{, 33}$ as distinct from universal rights. A common example of a right protecting group interests might be the right of a shareholder of a corporation to sue in the name of the corporation, which arises by virtue of the special status of corporate shareholder. A more fraught example of a right serving a group interest might be the right of a member of an Indian tribe to vote in elections for the government of a geographical territory that includes non-Indians but that is governed by officials elected exclusively by tribal members. ${ }^{34}$

30 Accordingly, I shall not discuss whether group rights ultimately benefit individuals. I shall analyse only the 'interests' protected by such rights.

See, eg Leighton McDonald, 'Can Collective and Individual Rights Coexist?', (1998) 22 Melbourne University Law Review 310. 
We can combine these two distinct concepts of group rights into a useful two-by-two table:

\section{Table 1}

\begin{tabular}{|l|c|c|}
\cline { 2 - 3 } \multicolumn{1}{c|}{} & Individual Interests & Group Interests \\
\hline Individual Right-Holder & 1 & 2 \\
\hline Group Right-Holder & 3 & 4 \\
\hline
\end{tabular}

The 'individual rights' that we considered in the previous section are located in Cell I of this table. They are rights, held and asserted by individuals, that protect individual interests. This makes visible yet a fourth limitation on the ability of individual rights to promote cultural heterogeneity. Individual rights protect only those interests that arise from common membership in a community, and they therefore cannot protect those interests that are specific to subordinate groups within the community. This sharply constricts the capacity of individual rights to encompass and protect the particular needs and aspirations of subordinate groups.

Cells 2-4 identify three distinct kinds of group rights, each of which must be analysed separately. Consider, first, the kind of group rights that are located in Cell 3. We might formulate the distinction between Cell 1 and Cell 3 in this way: If we specify that entity ' $E$ ' holds right ' $R$,' the transition from Cell 1 to Cell 3 varies the nature of $E$, while holding the content of $R$ constant. Because $R$ remains constant, the right in Cell 3 protects the same interests as the right in Cell 1. By contrast, the transition from Cell 1 to Cell 2 holds E constant, but varies the content of R.

We might thus imagine an individual property right (' $R$ ') that any person might hold in Blackacre. The description of ' $R$ ' is such as to protect 'individual' interests in property, meaning those interests that any person could hold in Blackacre. If we now imagine ' $R$ ' held by an Indian tribe, or by a church, or by a corporation, we will have described a right in Cell 3 . The content of ' $R$ ' does not vary, merely because it is held by a group. This implies that the interests protected by rights in Cell 3 afford no greater protection to groups than would be afforded by the individual interests that are protected by individual rights generally. Group rights in Cell 3 protect cultural heterogeneity only insofar as these individual interests protect that heterogeneity.

In Section II we noted three theoretical limitations on the protection offered by individual rights to cultural diversity. The first and third of these limitations would also seem to apply to rights in Cell 3. Cultural heterogeneity is protected only insofar as it is not inconsistent with the values served by the individual interests that justify the right, and cultural heterogeneity is not safeguarded from the effects on individual choices of cultural hegemony. The second limitation, however, which derives from the inconsistency between the individual autonomy and certain kinds of cultures, would not seem applicable, because in Cell 3 it is the 
group itself that exercises the right.

The fact that rights in Cell 3 are held by groups carries three important structural consequences. First, it empowers groups. When groups exercise rights they affect the world. They control resources and modify the behaviour of others. Groups endowed with these capacities are potentially strengthened and solidified. ${ }^{35}$

Second, authorising groups to exercise rights puts pressure on groups to institutionalise, so that they can assert rights. It is difficult to understand how disorganised groups can become rights holders, for the reason that the deployment of a right requires the kind 'unity of agency' that Christine Korsgaard has located in the exercise of practical reason. Institutional organisation is the social form by which such unity is typically constructed. ${ }^{36}$ To the extent that groups invest their identity in institutional forms, however, the potential grows for well-known dynamics of organisational power to take hold, and to split institutional form from group identity. This in turn might magnify any potential disparity between the culture of a group and the group institutions that are necessary in order to exercise a right. $^{37}$

Third, rights in Cell 3 authorise the state to recognise a right-holder as an authentic representative of a group. If there is a dispute about who may properly represent a tribe in the assertion of its property rights, for example, the state must settle the matter by determining the legal identity of the tribe. ${ }^{38}$ Similarly, if a church that holds property undergoes a schism, and if each branch of the church claims the property, the state must determine which claimant legally represents the church. ${ }^{39}$ This may give the state important leverage over the identity and development of groups.

Paradoxically, this leverage is augmented with respect to the kind of group rights that are located in Cell 2. This is because group right-holders almost always already possess the ability to act with a 'unity of agency.' But rights located in Cell 2 are asserted by individuals rather than directly by groups. The construction of the collective agency of the group is thus left entirely in the hands of the state.

Consider, for example, a society whose constitution guarantees $20 \%$ of the seats in its parliament to a particular ethnic group. Suppose that the group is not like a church or a tribe, because it does not possess an institutional form of agency empowered to speak on behalf of the group. The group interests protected by the right must thus be articulated by individual members of the ethnic group. In such

35 It is also possible, however, that control over the exercise of a group right in Cell 3 can become the object of internal division and tension within a group, and hence undermine group solidarity.

36 See Michael Hartney, 'Some Confusions Concerning Collective Rights', in Will Kymlicka (ed), above n 28, 214-16.

37 These divisions can sometimes exacerbate pre-existing tensions within the group. See, eg Michael R Anderson, 'Law and the Protection of Cultural Communities: the Case of Native American Fishing Rights,' (1987), 9 Law \& Policy 125.

38 See, eg William Claibome, 'United States Outs Tribe's Leaders', (August 11, 1999) The Washington Post A13.

39 See, eg Jones $v$ Wolf, 443 U.S. 595 (1979). 
circumstances, the absence of authoritative institutional presence renders the formulation of group interests highly susceptible to official interpretations of the state. National courts will have to determine both the identity of the group-who is a member of the group and who is not-and also the nature of the pertinent group interests.

Implicit in such decisions will always be a portrait of group relationships viewed from the perspective of the national culture. ${ }^{40}$ All special rights asserting group interests ultimately empower national courts to articulate the nature of these interests; in the absence of a competing and official self-representation by a group, such judicial articulations are likely to have great effect.

That having been said, it is also clear that special rights that protect group interests can facilitate broader and richer legal protections for cultural heterogeneity than can rights that protect only individual interests. This is because special rights protect interests that pertain to specific groups and that need not be shared by persons generally. The circumstances of particular groups, their history and social position, as well as the particular values of their cultures, can be factored into the legal formulation of a right. The members of a subordinate and threatened linguistic group might thus be endowed with special rights to protect their language, ${ }^{41}$ or the members of a peaceful but premodern religious group might be afforded immunity from general school attendance laws. ${ }^{42}$

By tailoring rights to the specific historical circumstances of particular groups, special rights can provide powerful support for cultural heterogeneity. They can convey a robust symbolic commitment to the ongoing strength and health of particular groups and to the cultural diversity represented by such groups. Such rights endow particular group interests with quasi-official status, and they thereby simultaneously bind groups to the state and create legal privileges toward which other groups can aspire. But it is also the case that the competition among groups for such official status can sometimes prove destabilising.

Rights protecting group interests intrinsically divide citizens into groups, and they divide groups from each other. For this reason, such rights put far more pressure on the unity required by constitutionalism than do rights protecting individual interests. This is particularly true for democratic states. I have argued elsewhere that democratic legitimacy ultimately rests upon the reconciliation of individual and collective autonomy, so that a democratic state must always maintain a relationship with its citizens, viewed as individuals. ${ }^{43}$ To the extent that rights protecting group interests imagine citizens as members of groups, rather than as individuals, they potentially create tension with this notion of democratic legitimacy.

$40 \quad$ For a discussion, see Robert Post, above $n 23$.

41 See Denise G Réaume, 'The Group Right to Linguistic Security: Whose Right, What Duties?', in Judith Baker, above n 33.

42 Wisconsin $v$ Yoder, 406 U.S. 205 (1972).

43 See, Robert Post, 'Between Democracy and Community: The Legal Constitution of Social Form', (1993) NOMOS XXXV ('Democratic Community') 163-90; Robert Post, above n 5, 1523-25. 
But this point should not be overdrawn. Various forms of group rights are quite common, and they do not seem to affect democratic legitimacy. Shareholder derivative suits, for example, require individuals to assert the interests of a corporation. They thus fall squarely into Cell 2, and yet they do not appear to call democracy into question. The tension to which I refer arises primarily when the group interests protected by a right are those that go to the identity of persons. ${ }^{44}$

The distinction might be illuminated by reference to Emile Durkheim's essay on 'Individualism and the Intellectuals,' in which Durkheim hypothesises that the 'moral unity' necessary for a legitimate state has come under increasing pressure as the division of labour has become more pronounced. ${ }^{45}$ Individualism is the modern ideology, par excellence, because in the circumstances of modern life the only remaining thing we have in common is our status as individuals. Individualism is thus the only ideology capable of sustaining the legitimacy of the contemporary, heterogeneous state.

Hereafter, to what can collective sensitivity cling? To the extent that societies become more voluminous and expand over vaster territories, traditions and practices, in order to accommodate themselves to the diversity of situations and to the mobility of circumstances, are obliged to maintain themselves in a state of plasticity and inconstancy which no longer offers enough resistance to individual variations. ...At the same time, as a result of a more developed division of labor, each mind finds itself oriented to a different point on the horizon, reflecting a different aspect of the world, and consequently the contents of consciousness differs from one person to another. Thus, we make our way, little by little, toward a state, nearly achieved as of now, where the members of a single social group will have nothing in common among themselves except their humanity, except the constitutive attributes of the human person in general. This idea of the human person...is therefore the only idea which would be retained, unalterable and impersonal, above the changing torrent of individual opinions...Therein lies all individualism; and that is what makes it a necessary doctrine. ${ }^{46}$

Those who advocate special rights in order to preserve cultural heterogeneity sometimes argue that cultural diversity should be protected because group culture is essential to the identity of persons. ${ }^{47}$ Special rights designed to protect distinct identities fly in the face not merely of the individualism characteristic of democracy, but also of the individualism that Durkheim

44

It is the case, however, that the competition among groups created by special rights may also be independently and contingently destabilising.

Emile Durkheim, 'Individualism and the Intellectuals', in Emile Durkheim, On Morality and Society (Chicago: Chicago University Press 1973) 50.

lbid 51-52.

See, eg Margalit and Halbertal, above n 21. I should stress that I am evaluating special rights in Cells 2 and 4 only insofar as they are designed to foster the value of cultural heterogeneity. I do not consider such rights insofar as they serve other purposes, such as remedying the effects of past discrimination, or distributive justice, etc. 
hypothesises must lie at the foundation of social solidarity in any modem, diverse society. A state that establishes special rights of identity must ask itself what its citizens have in common that will sustain the unity necessary for constitutionalism. If they do not share the common status of individuals, because they possess the (by hypothesis) distinct identities created by their groups, what binds them together in loyalty to a single constitution?

One can hypothesise that constitutional unity is achieved by a shared allegiance to the value of respecting diverse groups. But what underwrites this allegiance? It may be an agreement between heterogeneous groups to live together in mutual toleration and support. But then the constitutional state is envisioned as a kind of international peace treaty between groups. The unity necessary for constitutionalism persists only so long as it remains in the perceived interest of the component groups. When; as in Canada today or in the United States in the 1850s, this perceived interest fades, the state teeters toward dissolution. This kind of constitutionalism, then, imagines the unity of the modern state in purely contractual terms. It rests the legitimate stability of the state on a modus vivendi that depends for its endurance upon the continual confluence of strategic interests. ${ }^{48} \mathrm{~A}$ good example of such a contemporary modus vivendi is the constitution of the fragile state of Bosnia-Herzegovina, which reads like a treaty among the 'constituent peoples' of Bosnians, Croats, and Serbs. ${ }^{49}$

Alternatively, constitutional unity might flow from the solidarity of persons who each share the human need for significant group affiliation. The concept is that there is a universal human nature that requires group affiliation and that sustains national solidarity. In his early work, Will Kymlicka presented something like this picture as a justification for special rights. ${ }^{50}$ This concept is both attractive and consistent with Durkheim's hypothesis about the necessary sources of social solidarity in a modern state. There are, however, two theoretical limitations to the ability of this rationale to sustain the construction of special rights.

The first is analytic. Special rights protecting aspects of group identity inconsistent with the aspects of individualism deemed necessary for national solidarity are pro tanto illegitimate. For example, if the individual need for group identity is understood to require forms of affiliation that are voluntary, special

For a discussion, see John Rawls, Political Liberalism (New York: Columbia University Press 1993) 144-150. I owe to John Ferejohn the insight that the political stability of a modus vivendi can vary, depending upon the structural nature of the confluence of interests. The relationship between the parties to a spot contract differs from the relationship between the parties to a long-term relational contract. And, as the example of Europe indicates, a modus vivendi can dynamically evolve into stronger forms of solidarity.

49 See Fred L Morrison, 'The Constitution of Bosnia-Herzegovina', (1996) 13 Constitutional Commentary Zoran Pajic, 'A Critical Appraisal of Human Rights Provisions of the Dayton Constitution of Bosnia and Herzegovina', (1998) 20 Human Rights Quarterly 125.

so See Will Kymlicka, above n 34. For a discussion of this perspective in the context of American constitutional law, see Frank I Michelman, Brennan and Democracy (Princeton: Princeton University Press 1999) 119-33. 
rights significantly impairing the ability to exit from groups ought to be deemed illegitimate. $^{51}$

The second is dynamic. The creation of social identity is not static; it results from lived experience. If special rights, even special rights understood as founded on the universal human need to join groups, create social circumstances in which persons come in fact to identity with particular groups, instead of with a national state that is responsive to all individuals who need groups, then special rights will have acquired a social meaning and effect that endangers constitutional unity.

Special rights, therefore, potentially stand in analytic or dynamic tension with the prerequisites of constitutional unity. The nature and extent of this tension will no doubt entail both interpretation and practical assessment. It is often difficult and controversial to ascertain the social meaning of rights. Take, for example, the right to be free from discrimination on the basis of race that is contained in the Equal Protection Clause of the 14th Amendment of the United States Constitution. Some, like Cass Sunstein, wish to argue that assertions of this right always depend upon 'group-based claims' because they 'are necessarily based on complaints about treatment that singles out a characteristic shared by a group. ${ }^{, 52}$ Sunstein would thus locate the right in Cell 2 of Table I. He wishes to do so in order to defend affirmative action from the charge that it discriminates against whites based upon their race. He would therefore argue that the right to be free from racial classification applies to particular groups, by virtue of their history, but not to individuals generally.

This interpretation of the right, however, is highly controversial. The United States Supreme Court, for example, has repeatedly said that 'it is the individual who is entitled to judicial protection against classifications based upon his racial or ethnic background because such distinctions impinge on personal rights, rather than the individual only because of his membership in a particular group. ${ }^{53}$ The Supreme Court would thus characterise the right as an individual right, and it would locate it in Cell 1 of Table I. Because differing interpretations of a right correspond to different locations in Table I, the Table can help us understand the analytic tensions at stake in competing interpretations of a right.

Moreover, even if a court were to adopt Sunstein's analysis of the right to be free from racial discrimination, and even if a court were not to find any analytic tension between this interpretation of the right and the foundations of democratic

si See, eg Chandran Kukathas, 'Are There any Cultural Rights?', in Will Kymlicka (ed), above $\mathrm{n} 28,238$. The analytic tension is explicitly recognised in the report of the Australian Law Reform Commission on Multiculturalism and the Law: 'Multicultural policies are based on the premise that all Australians should have an overriding and unifying commitment to Australia.' The Law Reform Commission, Report No. 57: Multiculturalism and the Law (Sydney: Australian Law Reform Commission 1992), 9. 'The problem,' said the Commission, 'is to differentiate between those values which are necessary for cohesion and those which may be adjusted to allow for diversity.' Ibid 11.

52 Cass R Sunstein, 'Casuistry', in Robert Post and Michael Rogin (eds), Race and Representation: Affirmative Action (New York: Zone Books 1998) 317.

53 Adarand Constructors v Pena, 515 U.S. 200, 224 (1995). 
constitutionalism, our discussion suggests that a court would also have to assess whether the dynamic effect of such a right would be inconsistent with the social solidarity required for constitutional unity. This would account for the concern, repeatedly stressed by the Court in its affirmative action opinions, that interpreting equal protection as authorising special rights would effectively undermine 'the dream of a Nation of equal citizens in a society where race is irrelevant to personal opportunity and achievement, ${ }^{, 54}$ a dream the Court manifestly views as essential to constitutional unity. Just as the meaning of the right is subject to controversy, so is this assessment of the practical effect of the right. ${ }^{55}$

The effect of special rights can be quite controversial. Sometimes such rights appear as positive entitlements to specific goods, as for example the right to a particular proportion of representation in parliament or the right of members of a tribe to fish in specific ways. ${ }^{56}$ But sometimes these rights appear as immunities from the application of otherwise general laws, as when members of a particular group claim a 'cultural defense' to a criminal prosecution, ${ }^{57}$ or when members of a group claim that their culture requires immunity from generally applicable tort laws. 58 These immunities sometimes take the form of claims that the 'reasonable person' by reference to whom a defendant's liability is to be measured should be assessed according to the norms of a particular group, rather than according to the norms of the community as a whole. ${ }^{59}$

Special rights that confer immunities pose the more direct challenge to the national culture. This is because general regulations of interpersonal behaviour constitute a national culture's baseline of acceptable conduct, and exemptions from that baseline, even though justified by group norms, can easily be perceived as license to harm. Examples might include the claim that the norms of a particular culture should exempt its adherents from the enforcement of laws against polygamy, ${ }^{60}$ or clitoridectomy, ${ }^{61}$ or certain forms of parent-child sexuality. ${ }^{62}$ Special

Richmond v J.A. Croson Co., 488 U.S. 469, 505-06 (1989).

This may account for the curious fact that the Court, in other contexts, has viewed the constitutional recognition of racial (and gender) identity as a prerequisite for national solidarity. See, eg Taylor v Louisiana, 419 U.S. 522, 527 (1975).

Donald Parman, 'Inconstant Advocacy: The Erosion of Indian Fishing Rights in the Pacific Northwest, 1933-1956', in Robert L Nichols (ed), The American Indian: Past and Present (New York: McGraw-Hill 1992).

For a discussion, see Paul Mangarella, 'Justice in a Culturally Pluralistic Society: The Cultural Defense on Trial', (1991) 19 Journal of Ethnic Studies 65; Holly Maguigan, 'Cultural Evidence and Male Violence: Are Feminist and Multiculturalist Reformers on a Collision Course in Criminal Courts?', (1995) 70 New York University Law Review. 36.

See, eg Thomas Isaac, 'Individual versus Collective Rights: Aboriginal People and the Significance of Thomas v Norris', (1992) 21 Manitoba Law Journal 618; Carol Weisbrod, 'Symbols of Federalism', 25 University Michigan Journal of Law Reform, (1992) 795, 816-25.

See, eg Bitsie v Walston, 515 P.2d, 659, 662 (N.M. App. 1973). Reynolds $v$ United States, 98 U.S. 145 (1878).

Susan Okin, 'Is Multiculturalism Bad for Women?', (1997) 22 Boston Review 25-28. Farah Sultana Brelvi, "News of the Weird': Specious Normativity and the Problem of the Cultural Defense', (1997) 28 Columbia Human Rights Law Review 657. 
rights designed to protect the interest of the group in such practices simultaneously safeguard aspects of group identity from domination by the national culture and authorise behaviour which, from the perspective of the national culture (although not from the perspective of the subordinate culture) constitute harm.

This suggests that the distinction drawn by Will Kymlicka between 'external protections' and 'internal restrictions, ${ }^{, 63}$ which he views as of fundamental importance in evaluating the desirability of group rights, cannot be sustained. Kymlicka defines 'external protections' as involving 'the claim of a group against the larger society. ${ }^{64} \mathrm{He}$ argues that external protections primarily concern 'inter-group relations,' and that they involve issues of 'unfairness between groups' rather than of the oppression of individuals. ${ }^{65}$ 'Internal restrictions,' by contrast, involve 'the claim of a group against its own members,' hence directly raise 'the danger of individual oppression. 66

Special rights frequently confound this distinction, however, because they concern group interests both that define the group as against the larger society and that affect the individual freedom of group members. ${ }^{67}$ The distinction between external protections and internal restrictions does not offer useful guidance in evaluating such group rights. Instead, as I have suggested, inquiry ought to turn on whether the substantive group interests protected by a right are analytically or dynamically inconsistent with the individuality deemed necessary to sustain constitutional unity.

This analysis of special rights applies equally to rights in Cells 2 and 4 of Table I. The difference between these cells lies in the fact that special rights located in Cell 4 are held by groups, which will presumably possess the institutional structure necessary to deploy rights. An example might be the right of an established church to receive state funding. The institutional structure of a group capable of exercising rights will likely enable it to compete with the state in authoritatively articulating the nature of the group interests and group identity implicit in the nature of special rights. This will cede to the state somewhat less influence in these matters than with respect to rights located in Cell 2.

The retention of influence, however, comes at a certain cost, for special rights in Cell 4 furnish the state with direct access into the internal institutional structure of a group. Those who capture the right to speak for a group also capture the right to wield special rights granted by the state. Access to the state resources created by these rights thus becomes a prize to be won by competitive factions within the group. This can give the state leverage over internal struggles for power within the group, which the state can use to enhance national solidarity by co-opting group factions. This dynamic, in turn, can accelerate any potential

63 Will Kymlicka, Multicultural Citizenship (Oxford: Oxford University Press 1995) 35-44.

$64 \quad$ Ibid 35.

$65 \quad$ Ibid 36.

66 Ibid 35-36.

67 See, eg Ayelet Shachar, 'Group Identity and Women's Rights in Family Law: The Perils of Multicultural Accommodation', (1998) 6 Journal of Political Philosophy 1. 
divergence between institutional structure and group culture. Another possibility, however, is that the quasi-official resources available to a group endowed with rights located in Cell 4 can transform the group into a locus for cultural legitimacy and identification that rivals the state itself. How these divergent tendencies play out is matter of historical contingency and circumstance.

IV.

The group rights we have just considered in Part III consist of legal claims articulated and enforced within a national court system. This gives the national culture significant control over the centrifugal effects of such rights, because the substance of the rights can be defined and circumscribed in ways that render them consistent with national requirements.

In this section I shall consider a third mechanism for protecting cultural heterogeneity, a mechanism that sharply circumscribes this form of control. This mechanism is the devolution of sovereignty, and it may be defined as the national culture's ceding to a group the authority to make law. In contrast to the group rights discussed in Part III, which are defined and enforced by national courts that are ultimately responsive to the national culture, the full devolution of sovereignty occurs when groups receive the power to define and enforce their own legal standards. In the United States the primary example of the devolution of sovereignty is the institution of federalism, which effects a 'wide distribution of...sovereign powers' so as to protect a 'variety of... group life. ${ }^{68}$

Because the authority to make law is not a single thing, but a bundle of distinct capacities, the devolution of sovereignty is an immensely complex process that can assume multiple different forms. Groups can be authorised to make law for group members, or for all persons within a geographically defined territory, or for group members within a geographically defined territory. Groups can be authorised to make law, but not to enforce law. Groups can be authorised to make law about some subjects, but not others. Groups can be authorised to articulate legal standards whose ultimate interpretation will lie with national courts, as is the case today with the law of Australian states. Groups can be authorised to articulate legal standards that are subject to a more or less dense web of national side-constraints, ranging from national constitutional rights to national pre-emption, as is the case today with the law of states within the United States. National review of the legitimacy of group law might be relatively comprehensive and efficient, or it may be confined to narrow and extraordinary writs, like habeas corpus. ${ }^{69}$

Each of these different configurations bespeaks a different understanding of and commitment to the value of cultural heterogeneity. Each involves a different

68 Harold Laski, (1971) Studies in the Problem of Sovereignty 275. See Post, above n 23, 301-02. Federalism, of course, serves many interests other cultural heterogeneity. See, eg Robert Post, 'Chief Justice Taft and the Concept of 
kind and degree of national control over the potential centrifugal possibilities implicit in devolving sovereignty. Each configuration must be analysed on its own merits, in terms of its own particular history and dynamic.

What all these configurations of devolved sovereignty have in common, however, is the authorisation to a group to make law that reflects group interests and norms. This provides for a potentially fuller and more comprehensive protection of cultural heterogeneity than the mechanism of group rights. This is because devolving sovereignty alters the legal baseline by which normal interpersonal relationships are to be measured.

Within a national system, legal interests are apprehended as individual because they reflect the national community's perception of what is owed to every person. The baseline that specifies what counts as an individual interest and what counts as harm, is thus set by reference to the values of the national culture. Law reflecting the values of a subordinate group will set this baseline differently. It will serve values that the national culture may perceive as partial and anomalous. But these values will seem to the subordinate culture to be universal, because they will define what the subordinate culture believes every person within its community should be entitled to have safeguarded.

Devolving sovereignty may thus transform the distinction between individual and group interests. In a 19th-century Mormon state, polygamy might count as an individual interest, not as a group interest, because from a Mormon perspective every person might have the right to participate in a polygamous family. The devolution of sovereignty thus functions to normalise values that, from the perspective of the national culture, seem abnormal. Normalisation constitutes the most complete expression of group culture. ${ }^{70}$

National states that devolve sovereignty essentially offer local cultures the opportunity to benefit from the economic, political, and military power of a national state, while at the same time retaining the authority to express local culture. Federalist states can thus offer significant incentives to encourage the loyalty and participation of local cultures.

But at the same time the normalisation of local culture can significantly exacerbate tensions between cultural hetereogeneity and constitutional unity. The transfiguration of interests involved in devolving sovereignty may lead to direct contradiction between group law and national constitutional law. To the extent that constitutional norms can be abrogated by sovereign groups, these norms cease to provide a foundation for national unity. The task of bearing that foundation must thus be shifted to other constinutional provisions that retain national application. The question is always whether these provisions are adequate to the task of sustaining national solidarity. To the extent that they are not, the national state will

See, eg Mark D Rosen, 'Our Nonuniform Constitution: Geographical Variations of Constitutional Requirements in the Aid of Community', (1999) 77 Texas Law Review 1129; Mark D Rosen, 'The Outer Limits of Community Self-Governance in Residential Associations, Municipalities, and Indian Country: A Liberal Theory', (1998) 84 Virginia Law Review 1053. 
devolve into a consociation, a modus vivendi, the domestic equivalent of an international organisation sustained by agreement.

The challenge posed to constitutional unity by the devolution of sovereignty does not lie merely in the possibility of analytic contradictions between group law and constitutional requirements. The challenge can also be dynamic, because a sovereign group is more likely to become a locus of identification and legitimacy, and hence to pose a practical challenge to the stability and unity of a national state.

These are potentially powerful centrifugal forces to let loose in a democratic state. Whether they can be effectively contained depends entirely upon the methods used by the national state to retain control over the devolution of sovereignty, so as to ensure that group law is not inconsistent with the ongoing health of the national union. Each case of devolving sovereignty, therefore, will require assessment of the adequacy of these methods, in light of particular historical circumstances. Paradoxically, for example, greater sovereignty can be devolved to isolated and relatively powerless groups, like Indian tribes in the United States, because the threat to the preservation of national sovereignty will be relatively minimal.

The devolution of sovereignty raises yet another danger, which is sometimes referred to as the problem of "internal minorities. ${ }^{, 71}$ Typically persons are members of more than one group, and more than one group inhabits any given geographical area. If sovereignty is devolved to a subordinate group to govern a geographical area, therefore, it would in all likelihood have power over persons who are not members of the subordinate group, or over members of the subordinate group who also belong to yet other minority groups. These persons constitute 'internal minorities.'

Any heterogeneous democratic state maintains its own particular balance between the protection of group interests and individual interests. In healthy circumstances, this balance will protect what citizens of the state regard as the necessary prerequisites for national solidarity. But if a state devolves sovereignty to a subordinate group for the purpose of enabling the group to renormalise the law in favour of the group's own identity, we can expect that this same balance will not be reproduced within the jurisdiction of the group.

The unique structural challenge faced by internal minorities is thus that they encounter two distinct balances between individual and group interests. One is the balance that obtains in the national state; the other is the balance that obtains within the smaller jurisdiction. This means that the law must somehow reconcile two different representations of the minimum prerequisites for national solidarity.

From the perspective of the nation, this structural doubling appears as the question of whether aspects of a subordinate group's renormalisation of rights should be restrained, typically by the imposition of a national conception of individual rights. To restrain all aspects of the renormalisation would be inconsistent with the purpose of devolving sovereignty, which is to more fully promote the cultural values of the subordinate group.

$71 \quad$ Leslie Green, 'Internal Minorities and their Rights', in Will Kymlicka, above n 28. 
But from the perspective of internal minorities, any disparity between what is normal in the nation and what is normal within the smaller jurisdiction carries the potential for tension and dissonance. In the United States, for example, significant sovereignty has been devolved to certain Indian reservations, with the consequence that women have been deprived of rights that they would enjoy in national jurisdictions. $^{72}$ Indian women in reservations must thus face two distinct understandings of the entailments of their citizenship. The disparity generates structural instability. To the extent they are disadvantaged, internal minorities have reason to pressure the nation to restrict the devolution of sovereignty.

This tension must be resolved through law. The question is not merely one of structural instability. It also concerns the social significance of cultural heterogeneity. To restrict the devolution of sovereignty is to impair the ability of a subordinate group to use law to promote its own distinctive values. To fail to restrict the devolution of sovereignty is to countenance the constriction of the norms of an internal minority within the jurisdiction of the subordinate group, a constriction not deemed by the national culture to be necessary to maintain national solidarity. If we assume that democratic constitutionalism is not threatened by either alternative, this dilemma can be resolved only by further specifying the exact nature of the cultural diversity we wish to use law to promote. The devolution of sovereignty, in other words, acutely raises the substantive question of what forms of cultural diversity should receive legal protection.

72 See, eg Santa Clara Pueblo, above n 69, 49. 